\title{
RELEASEMENT AND SEDUCTION: HEIDEGGER AND BAUDRILLARD ON THE PRESERVATION OF ILLUSION IN THE EPOCH OF OBSCENITY
}

\author{
Marc Oliver D. Pasco \\ Ateneo de Manila University, Philippines
}

\begin{abstract}
This work interfaces the philosophies of Jean Baudrillard and Martin Heidegger. It hopes to contribute to both Heideggerian and Baudrillardian scholarship by employing Baudrillardian ideas in more effectively describing the historical happening of the so-called withdrawal of Being from man, which preoccupied much of Heidegger's body of work. The work argues that by re-visiting an earlier idea of Baudrillard, which he termed as seduction, one finds a possible way of navigating the obscenity of the current epoch of Being. Akin to Heidegger's idea of Gelassenheit or releasement, Baudrillard's concept of seduction invites one to allow the real to once again appear, no longer by way of subjective representation, but to let it appear in its very disappearance in hyperreality.
\end{abstract}

\section{INTRODUCTION}

In his book Broken Hegemonies, Reiner Schürmann $(2003,10)$ puts forward the idea of hegemonic fantasms - a referent that "enjoins us in a way of being, signaling to us what we have to be." These fantasms are "ultimate referents and supreme standards" (Schürmann 2003, 8) that legitimize and even coerce thinking into understanding truth in a particular historical epoch, instituting possibilities and impossibilities for an entire age. He discusses three main hegemonic fantasms: "the Greek dream of the one that holds together, the Latin fantasm of an order that makes nature the dispenser of justice, and the modern fantasm which is defined as the regime of consciousness that ends in the ideal of a referential self-consciousness" (Schmidt, 2005,2 ). By focusing on the modern fantasm, it may be said that the engine that powers and makes possible the happening and meaning of history in such an age is the dream not merely of absolute knowledge, but total control and domination by consciousness over Being that serves as the ultimate horizon of the real. From the Cartesian self-certain cogito to the Hegelian Absolute Spirit, consciousness is designated as the ground upon which every happening owes its historical reality to. In the philosophy of Martin Heidegger, the modern fantasm begins with self-certainty 
and reaches its apogee in the age of modern technology where both history and reality become a function of the blind drive towards ever greater control.

In his works, Contributions to Philosophy (Of the Event), Heidegger (2006) speaks of this modern fantasm through his idea of machination (Machenschaft). Machenschaft for Heidegger signals the abandonment of thinking by Being when history is essentially held hostage by the coercive and seductive power of the idea of mastery. He (2006, 12) writes:

Machination here means the makeability of beings, which produces as well as makes up everything such that only in this makeability the beingness of beings that are abandoned by be-ing (and by the grounding of its truth) determines itself. (Here, makeable is thought as "watchable"= watchful. And hence makeability is thought in the sense of producibility). Machination means the accordance of everything with producibility indeed in such a way that the unceasing, unconditioned reckoning of everything is pre-directed.

For Heidegger, the metaphysics of modernity, which serves as the basis for modern science and technology, is ushered in by the historical withholding of Beyng (Being?) of itself from man that destines man into a mode of comportment that responds to beings from the perspective of makeability or producibility. Machenschaft is closely intertwined with power (Macht) and violence (Gewalt). Power secures the willful exercise of violence that seeks nothing less than the total annihilation of individuality through various schemes of calculation. For Heidegger, mastery by way of calculation, violence through the measured exercise of power constitutes the essential unfolding of the relationship between man and Being in the modern epoch.

While today's age may still be construed as a function of the age of machination, as we would imagine Heidegger to think, it may still be asked whether there is a more nuanced and accurate way of depicting the contemporary epoch. While Heidegger's critique of modern technology has inarguably been vital in philosophically deciphering the historical events of the modern epoch, it remains important to ask whether his views are still specifically responsive to the contemporary era. In other words, may we venture to ask whether we have crossed over into a completely new epoch of Being's withdrawal from humanity?

It is my position that Jean Baudrillard's thoughts on simulation and hyperreality can provide us a more appropriate lens for what I call the epoch of the obscene, the age which succeeds the age of modern technology. We exist in a time of crisis, a turning point, a time when new decisions must be made with respect to the question of what it means to be, to be human, and to be human with others. We are in a transitional point in history, moving from the age of modern technology to the age of obscenity of the virtual and the hyperreal. Baudrillard $(2000,67)$ observes that:

By shifting to a virtual world, we go beyond alienation, into a state of radical deprivation of the Other, or indeed of any otherness, alterity, or negativity. We move into a world where everything that exists only as idea, dream, fantasy, utopia will be eradicated because it will immediately 
be realized, operationalized. Nothing will survive as an idea or a concept. You will not even have time enough to imagine. Events, real events, will not even have time to take place. Everything will be preceded by its virtual realization. We are dealing with an attempt to construct an entirely positive world, a perfect world, expurgated of every illusion, of every sort of evil and negativity exempt from death itself.

This is indeed the epoch of the obscene, where the happening of history becomes ontologically preceded by its virtual representation, it is a model or simulation, a time of the immediate sublimation of possibility into reality, where the enframing of modern technology starts to succumb to the hypertrophic and metastatic colonization of hyperreality over all aspects of daily human life. Hyperreality is the result of the eradication of the real and its representational double, destroying referentiality and meaning in the process. The epoch of modern technology transformed and reduced beings into objects and ultimately into Bestand or standing-reserve. But given the present state of affairs, it may be surmised that after the epochal transmutation of Being into objects, their perpetual visibility and replicability through virtual reality and various information and communications technology platforms, have caused their implosion into fractal components of self-repeating and self-grounding images that terminate in the obscenity of the hyperreal. This obscenity "begins precisely when there is no more spectacle, no more scene when all becomes transparence and immediate visibility, when everything is exposed to the harsh and inexorable light of information and communication" (Baudrillard 2012, 26). This is the epoch of the total mediatization of history, where media narratives precede reality, where the map, as Baudrillard states, precedes the territory, where the exponential growth of the amount of accessible information devours itself, and along with it, history as we know it. Before this current age, reality was seen as something to be unlocked, harnessed, and tamed. But the hegemonic fantasm of the self-certain subject which used to rule over modernity has been slowly eroded in this epoch, where the unadulterated fulfillment of the desire for exposure and information overwhelms and breaches the subjective distance from reality necessary for maintaining the illusion of knowledge and control.

In effect, this work initiates a dialogue between a philosopher that essentially started noticing the perilous symptoms of modernity in the atomic age and a thinker that lived through its fruition and experienced first-hand the eventual practical effects of a metaphysics that grounded itself in the certitude of the cogito in this obscene epoch of information. There is not much exhaustively comprehensive literature that interfaces Heideggerian and Baudrillardian ideas. This work hopes to contribute to both Heideggerian and Baudrillardian scholarship by employing Baudrillardian ideas in more effectively describing the historical happening of the so-called withdrawal of Being from man, which preoccupied much of Heidegger's body of work.

\section{A PRELIMINARY SKETCH OF BAUDRILLARD'S IDEAS ON HYPERREALITY}

Baudrillard begins his discussion of hyperreality by citing Borges' fable in which cartographers of an empire drew up a map so detailed that it ended up covering 
the territory exactly. The point is that the cartographers were able to perfectly copy reality in such a way that one can say it is as good as the real itself. However, Baudrillard observes that in today's epoch, it is the simulacrum or the copy that precedes the real (think of digital geo-mapping, deep fakes, and Google maps), and reality is not only eclipsed but is actually substituted by simulacra.

The key to understanding Baudrillard's notion of simulation and hyperreality is his idea concerning models. The operation of simulation is "neither discursive nor nondiscursive, but nuclear and genetic" (Baudrillard 1994, 2). Baudrillard envisions hyperreality as the end product of a total simulation based on computerized models produced by a code that produces a purely operational form of reality whose origin, function, and purpose become practically and metaphysically irrelevant. In the contemporary age of simulation, the model is not merely a representation of a reality but a functional representation that eclipses the real itself. For instance, insofar as running on a treadmill is supposed to simulate "real" running, the treadmill as a functional model of the union of the biological study of physical fitness and mechanical engineering, embodies the functional definition of "fitness" and creates an entirely new world of running around it, with its own speed, cadence, gear, and ambiance. Running on a treadmill is both real running and not, so to speak. It is not merely an imaginary rendering of real running but is the colonization of the real experience of running by the precession of its simulation as perfectly executed by the model. It is hyperrealized running. The hyperreal image not only hides the real, but it also displaces it and overwhelms representation with its absolute proximity, immediacy, and endless reproduction through the precession of the model, which exists solely in the sphere of operationability.

The epoch of hyperreality is the obscene erasure of the distance between spectator and spectacle that is used to protect the subject from absolute transparency unto itself by perfect reduplication. The existence of a mirror shields the subject from total visibility. However, in the epoch of the obscene, where mirrors are reproduced on a massive scale, representation becomes a reality where the vertiginous reproduction of signs, images, and information places the dream of reality beyond nostalgia and memory through the instantaneous, real-time rendering of its affects. As Baudrillard observes, "The end of the spectacle brings with it the collapse of reality into hyperrealism, the meticulous reduplication of the real, preferably through another reproductive medium such as advertising or photography. Through reproduction from one medium into another, the real becomes volatile, it becomes the allegory of death, but it also draws strength from its own destruction, becoming the real for its own sake, a fetishism of the lost object which is no longer the object of representation, but the ecstasy of denegation and its own ritual extermination: the hyperreal" (1993, 71-72). The endless and meticulous reproduction and proliferation of the real through the technological, informational processes of media precipitate the death of the real, its annihilation from the sphere of relevance. Hyperreality is the performance of the real's inchoate and inevitable disappearance from history--the meticulous murder of the real by the simulacrum. For him, "things visible do not come to an end in obscurity and in silenceinstead, they fade into what is more visible than the visible: obscenity" $(1990,11)$.

Insofar as the transformation of our understanding and experience of reality are concerned, the speculative strain of the metaphysics of antiquity has indeed given way 
to a more scientific and functional reckoning of the question of what it means to be. Reality is no longer merely an object of intellectual contemplation to be kept at a distance, but an invitation towards enterprise, where the novelty of techniques and perspectives for its dissection and magnification is rewarded not only by knowledge, but by predictive control, remote accessibility, efficient manageability, and immediate reproducibility. It is at this point where Heidegger's ideas on machination (Machenschaft) and Enframing (Gestell) may prove useful as historical and hermeneutic tools in understanding the philosophical underpinnings of the epochal shifts that brought about the requisite transformations of the way we stand in relation to the real from the way it was perceived as something out there to be seen and known into something on standby to be manipulated, reproduced, and simulated.

\section{MACHENSCHAFT AND THE REAL}

Between 1936 and 1940, specifically in his works Contributions to Philosophy and Mindfulness, Heidegger anchored his critique of the metaphysics of subjectivity in modernity with the idea of Machenschaft. Literally translated as machination, the ordinary definition carries the meaning of a certain plotting or devising a certain plan with a certain devious end in mind. However, in the second section of the Contributions, Heidegger $(1999,88)$ defines machination as:

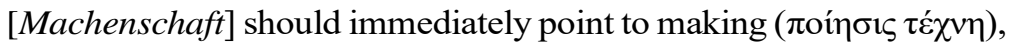
which we, of course, recognize as a human comportment. However, this comportment itself is only possible on the basis of an interpretation of beings which brings their makeability to the fore, so much so that beingness is determined precisely as constancy and presence. That something makes itself by itself and is thus also makeable for a corresponding procedure says that the self-making by itself is the

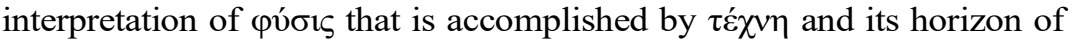
orientation, so that what counts now is the preponderance of the makeable and the self-making. . . in a word: Machination.

Machination holds sway over the modern epoch as the echo of the abandonment of Beyng of man as it hides itself in its essential concealment. Heidegger's Destruktion or historical critique of metaphysics finds its early articulation in the writings of the late 1930s, from his four-volume work on Nietzsche and the aforementioned works above. These writings speak of Machenschaft as the prevailing epoch which sends humanity on its way towards its destined oblivion of Being/Beyng. Machenschaft, Heidegger's early permutation of Gestell represents the apogee of subjectivity's willfull but essentially aimless march towards ever greater technologization. In this state of abandonment, humanity becomes caught up in the business of continuous calculation of probabilities with respect to the rate by which the world itself shall be completely objectified and mapped by the representations of subjectivity. Oblivious to the echo of the truth of being and lacking distress with respect to its perilous condition, humanity is left obsessed with calculation, acceleration, and massiveness. 
In calculation, humanity secures its destiny within the horizon of mathematical certainty. Calculation is the basis of all steering, planning, and experimentation that leads to further efficiency in managing beings, at the expense of the incalculable, which is assumed to eventually be assimilated into the realm of calculation (Heidegger $1999,84)$. Calculation projects in advance what it wants to see in reality. It plots all possible configurations of the real and reduces reality into numbers, essentially displacing the essential experience of reality as phusis and aletheia. When calculation forms part of the primary comportment of humanity in the world, the world itself becomes subsumed under the law of statistical probabilities and mathematical conjectures that are practically "allergic" reactions and form part of the violent domination (Gewalt) against the inherent mystery of the real. As Heidegger explains, "that interpretation of beings as representable and re-presented. In one respect, representable means 'accessible through intention and calculation'; in another respect, it means 'advanceable through production and execution.' But thought in a fundamental manner, all of this means that beings as such are re-presentable and that only the representable is" (Heidegger 1999. 76). In calculation, reality is a function of representation. Mathematics is not found in nature but constitutes a system of a priori stipulations projected by consciousness, which levels reality to fit in a particular ground plan that accommodates and assimilates, in strict adherence to a commitment to exactitude. Exactitude yields predictability, which then fosters the continuous production and reproduction of the real within the matrix of the calculable. The ontology of representation is exclusively a projection of subjective/scientific constitution.

Acceleration "means not-being-able-to-bear the stillness of hidden growth and awaiting; the mania for what is surprising, for what immediately sweeps [us] away and impresses [us], again and again, and in different ways" (Heidegger 1999, 84). Humanity's calculative disposition towards the real necessarily involves an obsession with speed. The recently deceased cultural critic, Paul Virilio $(1991,100)$, said that "With speed, the world keeps coming at us, to the detriment of the object, which is itself now assimilated to the sending of information." Acceleration views the enhancement of reality and humanity's experience of it in purely quantitative terms categorized mainly in terms of data. More experiences, more knowledge, more areas covered in the shortest amount of time is the teleological motivation behind the fascination with acceleration. As Heidegger $(1999,84)$ says, "Its place is taken by the restlessness of the always inventive operation, which is driven by the anxiety of boredom". Acceleration does not have the patience to allow the moment to while away, so to speak - to let it unfold in accordance with its own nature. Just think of how an innocuous gadget like a smart tv remote gives us a sense of power over time and displaces the experience of temporality, of having-to-be-in-the-present-anticipating-the-future. Acceleration corresponds to humanity's inability to tarry with what calls for attention, as it is perpetually distracted by the anxiety of having always to be one step ahead of unconcealment.

Calculated and accelerated reality defines what Heidegger calls lived experience (Erlebnis), in that "only what presses forth into the sphere of live-experience, only what man is able to bring to and before himself, [only that] can count as 'a being", (Heidegger 1999, 90). In this respect, only that which is lived out or experienced by subjectivity counts as real. The object-ness of the real is constituted by the calculative operations of the subject, which therefore begs the question, "What makes reality, 
real?" Reality becomes a construct, an object to be produced, taken in hand, manipulated, and curated to be fashioned in accordance with current human ends.

Thirdly, the outbreak of massiveness corresponds to humanity's predilection for what is popular and what is deemed relevant by the public. As Heidegger says, "What is common to the many and to all is what the 'many' know as what towers over them. Hence, responding to calculation and acceleration, just as on the other hand calculation and acceleration provide massiveness with its track and scope" (Heidegger 1999, 85). Calculability and acceleration necessarily lead to the representation of the world as revealed through the eyes of what is common and easily accessible to all. Opinion is the language of massiveness, but opinion not in the sense of irrational sentimentality, but its opposite - rational calculability, which gains the approval of all, oblivious to that which has abandoned thinking a long time ago. Events that get humanity's attention are manufactured events, spectacular displays of novelty and ingenuity that cater to the curiosity of the everyday man. The real becomes what everyone perceives as real, and calculative science, as the language of reality, reduces reality to how everyone judges what counts or does not count as real.

The epochal reign of machination, calculability, acceleration, and the outbreak of massiveness lead to what Heidegger calls the epoch of total lack of questioning and enchantment. The leveling down of possibilities, the triumph of the average, and the pervasive spread of mindless curiosity are essentially a function of how the real is revealed in the age of Machenschaft. The lack of questioning, or as Heidegger says, the lack of distress in the age of machination "is the greatest where self-certainty has become unsurpassable, where everything is held to be calculable and, above all, where it is decided, without a preceding question, who we are and what we are to do-where knowing awareness has been lost without its ever actually having been established that the actual self-being happens by way of a grounding-beyond-oneself, which requires the grounding - space and its time. This, in turn, requires knowing what is ownmost to truth as what knowing cannot avoid" (Heidegger 1999, 87). When lived-experience or representation becomes the default comportment of humanity with respect to the real, the make-ability of reality is brought to the fore as a function of the oblivion of humanity's ennownment to Beyng. Representational thinking produces the object as that which is natural (not in the sense of phusis) or as that which is beyond the reach of questioning - the logical and self-evident.

The epoch of Machenschaft finds its mature elaboration in the later works of Heidegger when he includes Gestell, Bestand, and Herausfordern to the lexicon of essential words that illumine the epochal transformation of the real in the age of modern technology. The ordering tendency, the domination of representation, and the unabated exercise of power over beings set up the "age of the world picture." Enframing, the essence of modern technology, secures for the epoch of withdrawal, its culmination - the annihilation of objects into standing-reserve.

\section{THE REAL AS A PICTURE, THEN AS STOCKPILE}

In The Question Concerning Technology, Heidegger $(1977,4)$ claims that "the essence of technology is nothing technological." He argues that the view which 
interprets technology within the context of instrumentalization misses the more essential point of understanding it as a way by which reality is revealed to us. He traces the etymological affinity of techné with poiésis and phusis, claiming that all are modes of alétheia. What is crucial, however, is to think about the distinguishing trait of modern technology. Heidegger says that modern technology works within the ambit of a kind of revealing that not only reveals beings as objects of representation under the aegis of the subiectum. The essence of modern technology as a historical event of truth to which humanity responds challenges human beings to reveal the real not only as objects of representation but as stockpile, as "stuff" that must always be ready for further ordering, always on standby, available and readily at one's disposal.

In the Age of the World Picture, Heidegger $(1977,134)$ says that "The fundamental event of the modern age is the conquest of the world as picture. The word 'picture' [Bild] now means the structured image [Gebild] that is the creature of man's producing which represents and sets before". In other words, man, as subiectum, weaves the fabric of the real, as if he was standing as opposed to it as its maker. If representation builds a picture of the real, Gestell breaks down the image within the frame, breaks it down to pixels, and stores it for further enhancement, reconfiguration, and recycling, so to speak. The real is that which is recyclable, i.e., that which is always ready to be re-purposed and restored behind what actually shows itself as a picture. Being, reduced to standing-reserve or Bestand represents the nebulous potentiality of the real to be further actualized in a manifold of ways. Responsive to the unconcealment of Being, humanity not only restlessly looks for more reality to make, it aggressively stockpiles the real for the sole purpose of accumulating more permutations of reality that can be exploited for further stockpiling. The real as a picture is eclipsed by its own mutation into standing-reserve. Bestand represents a "picture" of reality in maximum activity through the total positivization of potentiality, availability, and malleability. The real as stockpile should not only be understood as the transformation of everything into objects or things kept ready for use. The real as standing-reserve is the dissolution of the object itself as it transforms into pure energy, ready to be whatever it can be as deemed necessary by the historical destining of the withdrawal of the essential unfolding of reality as alètheia. Bestand is the real viewed as energy, unlimited by form and boundless in potential. While Machenschaft emphasizes the representability of the real as an object of scientific construction, Gestell goes beyond the object-ness of objects and underscores the almost transmetaphysical character of the real-as pure, potent, reproducible energy, the primal clay of creation, as it were, with which the real as we know it is permitted to stay around and linger for a while until destining itself finds a new purpose for it.

The practical consequence of the reign of Enframing for post-industrial society in the late twentieth century, specifically with the digital revolution in the field of information and communication technologies, is the radical reproducibility and enhanced rendering of the virtual as a substitute for the real. Heidegger had always thought of himself as a preparatory thinker. His thought, as he himself had described, are pathmarks (Wegmarken) that, if one follows, may lead one to a clearing (Lichtung). As such, it is only necessary that those who follow his lead become attuned to the possibilities proffered by his thoughts. It is the position of this work that Enframing, the essence of the epochal sending of Being in the age of modern technology, is not 
the final phase or consummation of the metaphysical oblivion of humanity from Being. There is a succeeding historical phase of the real, which Heidegger, having died in 1976, was not privy to. Before one sets one's eye to the so-called "turning" of Being, one sees that reality as we know it in the post-industrial society, has been transformed into something other than Bestand. The latent possibilities within the ambit of the unconcealment of the real as standing-reserve, as energy, has in fact given rise and morphed into a distinctly postmodern form of an object, but an object that transcends the language of machination or representation. In other words, the stockpile, the energy is no longer simply on standby, useful only at the behest of subjectivity that deems it as a resource for its projects.

Machination and Enframing are both correlatives of a particularly scientific/mathematical certainty that necessarily takes for granted the question of whether the real is indeed what representational certainty purports it to be. But what if by some chance, some happening, the real "decided" to disentangle itself from the clutches of subjectivity and extinguished its secret by being perpetually exposed, simulated, and reproduced? What if, after its transformation into the endless possibilities maintained under the auspices of Enframing, it was able to actualize itself into a new form that challenges the traditional framework of the subject-object dichotomy that is grounded in certitude? In other words, what if the real became more real than what we thought of it, and its truth too true to be doubted ala Descartes, such that certitude is bypassed, leaving humanity in a state of schizophrenic stupor?

Baudrillard names this postmodern object the hyperreal - that which is more real than the real. Hyperreality is a simulation that defies the logic of the subject-object representation and reveals the real not only as a stockpile, but as that which undercuts the processes of representation and imagination, as always already reproduced, consumed, and virtually connected to. The hyperreal is the image of the real that has taken over, displaced, and replaced the original object. In so doing, it effectively extinguishes the real as we know it, not by dissolution, but by nihilation through infinite reproduction and proliferation. This then inaugurates a new metaphysics of the no(thing); i.e., a metaphysics of the real as a thing no longer (traditionally understood as res extensa or even as energeia), but of the real, as constituted beyond the auspices of the subject-object relation thereby undermining the constitutive powers of the subject with respect to what it encounters.

This epochal development in the history of Beyng succeeds the epoch of modern technology, and this work calls this the epoch of obscenity. These two ages are not mutually exclusive but represent an epochal continuity within which the destined oblivion of Beyng remains. In other words, obscenity is a necessary historical consequence of machination and Enframing. The very possibility of simulation and hyperrealization of the real was already incipient within its purview being revealed to humanity as representation and stockpile. Viewed from the position of the digital age of information, Heidegger's description of the age of modern technology appears to shift from a purely exclusive modern critique of the dominant anthropocentric scientific worldview into a postmodern prologue for what was to come. The obscene is the progeny of technology, not solely in functional terms, but more importantly, it is its metaphysical successor with respect to how the real is revealed to humanity in the current epoch. As hyperreal, the real is obscene, too real, and too close for comfort, 
negating the once safe space of rational subjective representation by way of its instantaneous simulation, radical availability, infinite reproducibility, and total visibility.

When Heidegger spoke of the Rhine river, lamenting the loss of humanity's poetic experience of water to the power of Enframing that reveals the water as mere standing-reserve for energy demand, the hydroelectric power plant did not reveal itself as obscene. It still fell within the purview of subjective metaphysical representation. Today, however, when humanity's experience of water is the bottled mineral waterwater infinitely reproduced in a series without any reference to an origin, always already cleansed, reproduced, and deployed for anonymous consumption, the reality of water itself becomes obscene. It becomes more water than water-hyperwater, cleansed of every microbe, sanitized and distilled, yet alienated from the technological processes that produce it, maintaining a life of its own devoid of technological origin, populating every nook and cranny of consumer culture, obscenely ubiquitous, eradicating the difference between need and luxury, clean and unclean, resource and waste. Hyperreality is precisely like bottled water, neither an exploitable resource nor a poetic reminder of the fourfold. It is water stripped of both technology and illusion; it is more water than water. The metaphysics of hyperreality is defined as the eradication of the real by exterminating any semblance of illusion and nullifying absence and withdrawal through interminable presence.

\section{THE REAL AS HYPERREAL}

The current digital revolution, prefigured in the rise of the network society, brokered by the global use of the internet, saw a historically unprecedented expansion of humanity's virtual perception of its lifeworld. In fact, as early as the rise of radio and television broadcast media, Marshall McLuhan (2003, 420) had already foreseen how these new "extensions of our central nervous system" would eventually lead to a global village where connectedness through information would be of chief value. Dreyfus and Spinosa $(2003,318)$ observed that the shift from modernity to postmodernity had transformed the subject from one who was obsessed with collecting objects through representation into a protean being that is in constant search for information and connection. Mikkel Tin $(2010,868)$ further claims that "In a world of simulacra there is neither grounding nor phenomenon, there is nothing but a circuit of reflexes." Slavoj Zizek (1999) likewise warns of the immersive capabilities of the digitalized universe of simulation that can precisely implode the ontological difference between the Real and the Imaginary especially from the perspective of "those who see in it a dystopian prospect of individuals regressing to pre-symbolic psychotic immersion, of losing the symbolic distance that sustains the minimum of critical/ reflective attitude (the idea that the computer functions as a maternal Thing that swallows the subject, who entertains an attitude of Incestuous fusion towards it)" (1999, 111). These various perspectives on the status of the real and its relation to the subject in postmodernity all suggest a particular sense of paranoia - a cautionary tale of being trapped within an imploded universe, where sensory data is so extremely dense that subjectivity has no other choice but to retreat by surrendering the fort of representation to the now obscene 
configurations and reproductions of the once represented, previously known as the object. According to Baudrillard (1996, 30), hyperreality

...has nothing to do with representation, and even less to do with aesthetic illusion. The whole generic illusion of the image is canceled out by technical perfection. As hologram or virtual reality or threedimensional picture, the image is merely the emanation of the digital code which generates it. It is merely the mania for making an image no longer an image or, in other words, it is precisely what removes a dimension from the real world.

The virtual image, in this case, is precisely the extermination of the real by the deletion of its counterpart - an illusion. In this sense, Baudrillard argues that the perfection of the real's double, the ultra-accurate rendering of its copy, is essentially more real than the real because it is able to transcend the duality of truth and falsity by way of the total subversion of the question of the real itself, and this is precisely the logic of the hyperreal. The death of illusion simultaneously spells the extermination of the real. In making this claim, Baudrillard alludes to Heidegger and says, "With virtual reality and all its consequences, we have passed over into the extreme of technology, into technology as an extreme phenomenon. Beyond the end, there is no longer any reversibility; there are no longer any traces of the earlier world, nor is there even any nostalgia for it. This hypothesis is much graver than that of technological alienation or Heidegger's Gestell' (1996, 33-34). This statement openly shows Baudrillard's thoughts on the limit of Heidegger's critique of modern technology. While it must be submitted that technology does play a role in the hyperrealization of the contemporary epoch, hyperreality itself is something that goes beyond the radical objectivization of the real into standing-reserve. The hypothesis, while still falling under the scope of Heidegger's understanding of truth as unconcealment, nonetheless imparts a novel perspective in discourses concerning the very possibility of a retrieval (wiederholung) of the original truth of Being in an epoch where the very notion of truth as certitude is seemingly undermined by the collapse of certitude by way of its hyper-double - the radical indifference of subjectivity with respect to what reveals itself. In other words, hyperreality no longer incites questions of credibility or fidelity but operates independently of these categories as such. The unquestioning acceptance of the current generation towards the colonization of the virtual over the Lebenswelt is a testament to the power of this current destining of Being's historical withdrawal. As Baudrillard $(2000,200)$ astutely remarks:

In this precise sense, the commonplace according to which the problem with cyberspace is that reality is virtualized, so that instead of the flesh-and-blood presence of the Other, we get a digitalized spectral apparition, misses the point: what brings about the 'loss of reality' in cyberspace is not its emptiness (the fact that it is lacking with respect to the fullness of the real presence) but, on the contrary, its very excessive fullness (the potential abolition of the dimension of symbolic virtuality). 
Baudrillard claims that ours is a time of "promiscuity, of total contiguity" $(2015,44)$. The epoch of the obscene discharges the power of the hyperreal by abolishing the distance between scene and spectator, resulting in the radical positivization of the real - the total visibility of the real in its scene-less proximity, along with the dissolution of the line that used to demarcate the boundaries between fact and fiction, real and fake, subject and object. Comparing the current epoch of obscenity to the modern age of representation, Baudrillard $(2003,27)$ expounds:

'Scene' and 'obscene' do not, of course, have the same etymology, but it is tempting to connect the two. For as soon as there is a scene or a stage, there is gaze and distance, play and otherness. The spectacle is bound up with the scene. On the other hand, when we are in obscenity, there is no longer any scene or stage, any play, and the distance of the gaze is abolished. Let us take the pornographic sphere: it is clear that in pornography, the body is, in its entirety, realized. Perhaps the definition of obscenity might be, then, the becoming-real, the becoming-absolutelyreal, of something which until then was treated metaphorically or had a metaphorical dimension.

In the epoch of the obscene, the real becomes a fetish, an irrational indulgence that transgresses the metaphysical rules which distinguished being from non-being by way of immediate availability and instantaneous reproducibility. When the illusion is decimated by the technical perfection of simulation, reality loses the possibility of semblance, of negation, which anchors it within the realm of traditional metaphysics. Even Plato needed the shadows to produce the possibility of the Forms. In obscenity, shadow and reality implode and collapse into one another, resulting in a mesmerizing extravaganza of radical profusion, neutralized only by the limits of its own making. When everything is exposed to the light of digital information and virtual simulation, when nothing escapes the search parameters of the internet, when everything that has been written, photographed, video-recorded, made, have been digitally rendered and virtually roams cyberspace are simultaneously available for everyone at any time, the world itself becomes nothing but a carcass of the virtual, a memento of a deserted world where human beings used to live. These are not mere shadows, nor copies, or replicants, but hyperreal entities that expose more of the real than ever before. Baudrillard $(2001,29)$ reflects on what happens in pornography to illustrate his point:

The obscenity itself burns and consumes its object. One sees from up close what one has never seen before; to one's good fortune, one has never seen one's genitals function from so close, nor for that matter, from so general a perspective. It is all too true, too near to be true. And it is this that is fascinating, this excess of reality, this hyperreality of things. The only phantasy in pornography, if there is one, is thus not a phantasy of sex but of the real and its absorption into something other than the real, the hyperreal. Pornographic voyeurism is not a sexual voyeurism, but a voyeurism of representation and its perdition, a dizziness born of the loss of the scene and the irruption of the obscene. Consequent to the 
anatomical zoom, the dimension of the real is abolished, the distance implied by the gaze gives way to an instantaneous, exacerbated representation, that of sex in its pure state, stripped not just of all seduction, but of its image's very potentiality. Sex so close that it merges with its own representation: the end of perspectival space, and therefore, that of the imaginary and of phantasy - end of the scene, end of an illusion.

The pornographic scene effectively eradicates the traditional meaning of a scene, i.e., a situation involving spectator and spectacle, where the latter is constituted by the gaze of the former, its meaning a function of intentionality. Such is the absurd anatomical zooming-in to genitalia, unrecognizable due to the sheer proximity and total reality of what appears. Pleasure, if this truly ever was the intention behind the production of pornography, is not grounded in the seduction of sexuality or the fascination with the Other, but emanates from the banality of exposure, of seeing for the sake of seeing, which might constitute a fetish in itself. The spectacle consumes itself in the pornographic. It is essentially onanistic, feasting on its own desire to expose itself, bereft of any deception or illusion, reality robbed of its secret, raped not by mere curiosity, but by fetish in highdefinition, accommodating all possibilities of intentionality, motive, and utility. The real in the age of simulation is pornographic for Baudrillard. It reveals itself in its naked glory, pacifying the urges of representation, stunting the advance of objectivity by valorizing transparency. Objectivity craves the challenge of opacity. The transparency produced by the pornographication of the real in simulation inverts this desire and transmutes it into stupefied fascination - the blasé attitude of contemporary humanity towards everything it witnesses. When one sees everything, one sees nothing. Immersed in a pornographic world, we seek refuge from this total transparency not by retreating to subjectivity but by inane complicity, letting what shows itself show itself as if it didn't matter anymore.

Schizophrenia becomes the primary condition of the subject in the epoch of obscenity, the cause of its own withdrawal in the imploded dialectic between representation and reality. The schizophrenic is not defined in its ordinary sense as a condition of losing touch with the real. Scizophrenia in this context is defined as a state of total vulnerability, the crumbling down of the fort of representation against the overwhelming inertia of information and simulation. This condition drives subjectivity to look at multiple places at the same time (think of how computer browsers have developed from a solo interface into a multiple browser interface, allowing the user to essentially multiply his gaze). Baudrillard $(2012,30)$ explains:

The schizophrenic is not, as generally claimed, characterized by his loss of touch with reality, but by the absolute proximity to and total instantaneousness with things, this overexposure to the transparency of the world. Stripped of a stage and crossed over without the least obstacle, the schizophrenic cannot produce the limits of his very being; he can no longer produce himself as a mirror. He becomes a pure screen, a pure absorption and resorption surface of the influent networks.

The person with schizophrenia is a victim of the obscene and the unwitting prey of the screen. The docility of the real to the rule of hyperreality is evidenced by the 
negation of the distance between spectator and spectacle, where in effect, the gaze ironically becomes a function of reality's disappearance in its simulation. Baudrillard foresees a future where "there will no longer be any thought-sensitive surface of confrontation, any suspension of thought between illusion and reality. There will be no blanks any more, no silences, no contradiction-just a single continuous flow, a single integrated circuit" $(2009,40)$. One can envision Leibniz' monad as the model of human subjectivity in the near future. Everyone will casually be connected to "life" by way of the screen as they hover aimlessly like satellites in cyberspace entertaining casual visits from the "real world" if only to feed their bodies that may soon enough find nourishment through cybernetic means and therefore liberate itself from the earth as we know it. The screen will no longer project imitations or virtual renderings of the real but will become the primary scene of existence.

The epoch of the obscene is the post-metaphysical implosion of the, on the one hand, the machination of the technological, and the simulation of the hyperreal, on the other. The traditional metaphysical claims to the grounds of the real must be reevaluated in light of its latest epochal permutation as hyperreality. When subjective representation is short-circuited by the automatic operations of virtual simulation, one must try to find a new Archimedian point, so to speak, if only temporarily (under erasure, as Derrida would say), so that the principle of the real might still be salvaged, whatever may be its current form or mode of unconcealment.

\section{BAUDRILLARD'S SEDUCTION: THE OBJECTION OF THE OBJECT}

Baudrillard's intimations on the obscene are premised on a longing for secrecy and illusion. Historically, reality was always seen as an overcoming of illusion, but never its exterminator. Reality did not kill illusion; it preserved it by asserting its metaphysical, ontological, epistemological, and ethical supremacy over it. Even Plato had a place for the shadows, Christianity has had its extended battle with concupiscence after the Fall of Man but continued to confirm its existence with its perpetual call for confession and renewal. Descartes' cogito needed God to keep the deceptive or illusory power of the senses at bay, Kant maintained the necessity of an epistemological humility with respect to the really real as knowledge may be interpreted as a form of rationally necessary illusion, and Heidegger maintained the radical importance of concealment in making space for a clearing. Baudrillard maintains that "the 'murder of the Real' (Baudrillard's phrase) does not occur in a world of imagination, illusion, and magic, but in a world devoid of them" $(2008,66)$. He $(1990,65)$ adds, "For something to be meaningful, there has to be a scene, and for there to be a scene, there has to be an illusion, a minimum of illusion, of imaginary movement, of defiance to the real, which carries you off, seduces or revolts you." The proximate distance between the subject and the object is actually the domain of the object. The distance covered by representation simultaneously marks the withdrawal of the object into secrecy. He $(2000,75)$ adds:

"Knowledge" normally implies a dialectic between subject and object, a field of representation where the subject is master of the game since the subject constructed the frame of representation and projected it into the 
world. This presupposes the privilege of the subject and the concomitant inferior status of the object, including the scientific object. But knowledge rules over truth and causal relations, not over appearance or illusion. In the domain of the illusion, knowledge is no longer logically possible, for its principles and postulates cannot function. And this is not just a metaphysical insight: today, the microsciences stand at the point where the object as such no longer exists. It vanishes, it escapes, it has no definite status, it only appears in the form of ephemeral and aleatory traces on the screens of virtualization. At their outer edge, the most advanced sciences can only verify the object's disappearance. In other words, they can only verify the way the object plays with its own objectivity. This is the object's perverse strategy; perhaps it is a form of revenge. Apparently, the object is a trickster, foiling all the protocols of the subject's experiment so that the subject itself loses its position as subject.

Baudrillard here alludes to quantum physics, where scientists have experienced the uncanny behavior of particles that seem to defy the expected outcomes of the scientific method, behaving as if they knew they were being watched, evading the totalizing gaze of objectivity by way of radical movement and relativity. He opines in effect that the object may very well be not just a docile fetish for subjectivity but has within itself the capacity to elude the dialectic of meaning by reversing the gaze of the subject towards it. The insatiability of knowledge, its patent appetite, the conatus essendi of Spinoza, the assimilative gaze of the Same in Levinas, is merely a function of the nauseating opacity and density of the object in its Sartrean sense. He thinks that against the total positivization and exposure of the world in hyperreality, one must save the seductive illusion of the objective. He expounds, "Against the extermination of evil, of death, of illusion, against this Perfect Crime, we must fight for the criminal imperfection of the world. Against this artificial paradise of technicity and virtuality, against the attempt to build a world completely positive, rational, and true, we must save the traces of the illusory world's definitive opacity and mystery" $(2000,74)$. In response to the assimilative function of representation, Baudrillard proposes the possibility of seduction by the object. To be seduced is to be drawn by the elusively enigmatic, by that which escapes the totalizing gaze of information and communication, it is to be devoured by the secret of the object, to be captivated by its appearance, its illusion. Seduction leads us astray from the projected path of knowing into the world of illusion. Tracing its roots from the Latin, il-ludere, which means 'in play,' Baudrillard somehow echoes Derrida's concept of differance that highlights the necessity of deferring the process of totalization by recognizing the flux and instability inherent in the meaning of the real. While production is the prevailing logic of obscenity and hyperreality, "seduction is, at all times and in all places, opposed to production. Seduction removes something from the order of the visible, while production constructs everything in full view, be it an object, a number or concept" (Baudrillard 2001, 34). Ironically enough, I think it is actually this work from 1979 that provides a response to his seemingly bleak ruminations from 1981 onwards.

The modern project of total enlightenment, its drive towards ever-increasing knowledge and control, has precipitated the epoch of the obscene. Ridding the world 
of appearances by displacing it with more and more reality has only ironically led to the catastrophic dissolution of the real by its being too meaningful because of being too exposed. The challenge of seduction is to let the object appear in its disappearance, to allow appearance to happen beyond the pornographic exposure of obscenity. It is to challenge the obscenity of the world where nothing appears anymore because everything has always already been produced as a visible sign. As Baudrillard (1996, 16-17) expounds:

The proliferation of reality, its spreading like an animal species whose natural predators have been eliminated, is our true catastrophe. This is the inevitable fate of an objective world. We have to restore the potency and the radical meaning of illusion, which is most often reduced to the level of a chimaera diverting us from what is true: what things deck themselves out in to hide what they are. When, in fact, the illusion of the world is the way things have of presenting themselves for what they are when they are not actually there at all. In appearance, things are what they give themselves out to be. They appear and disappear without letting anything at all show through. They unfurl without concern for their being or even for their existence. They signal to us but are not susceptible to decipherment. On the other hand, in simulation, in this giant dispositif of meaning, calculation, and efficiency that encompasses all our technical devices, including current virtual reality, the illusion of the sign is lost, and only its operation remains. The happy non-distinction between true and false, between real and unreal, gives way to the simulacrum, which consecrates the unhappy nondistinction between true and false, between the real and its signs, the unhappy, necessarily unhappy, destiny of meaning in our culture.

Baudrillard's bargain seems to hinge upon the premise that despite the colonization and domination of hyperreality in the epoch of the obscene, the object asserts its objection, as it were. It stands its ground. The object is now interpreted as a singularity - representing absolute uncertainty, a point of infinite possibilities, in other words, of play. In astrophysics, the singularity is understood as the point in space-time where the radical density of a particle resulted in the Big Bang. Baudrillard uses this as a metaphor for the object in seduction, where the object becomes non-interchangeable, a sui generis, exempt from the system of exchange and the symbolic laws of value, radically other than any of its representation. The object as a singularity represents a revolt, an insurrection against the totalizing mechanisms of hyperreality.

Baudrillard's idea of seduction, of the object's revenge, is a viable counterpoint to the obscenity of the age. In his studies of the works of the anthropologist Marcel Mauss and the thinker Georges Bataille, Baudrillard became interested in the idea of a gift that cannot be returned in primitive societies. This so-called accursed share is an object which does not enter into the commerce of economic exchange, but that which cancels power and debt, as a counter-gift, a singularity that is symbolic of an excess the resides outside the logical equivalence of value in capitalist societies. Baudrillard $(2003,3)$ believes that the object in symbolic exchange "has a life of its own." This idea of radical alterity is a 
fatal strategy (a strategy that takes the side of the object, invested in the belief that the object can outwit the subject) against the hegemonic systems of obscenity in capitalist society. It is a call to keep one's distance from the object, to let seduction take place, instead of production, to allow the object to remain elusive and illusive, to let it remain at play. It is as he $(2005,15)$ says, to preserve the "tremor" of the image:

There is an aphorism by Lichtenberg that speaks of "tremor." Indeed, all gestures, including the most assured, begin with a tremor, like a fuzziness of motion. And there is always a trace of it left behind. Without that tremor, that fuzziness, when a gesture is purely procedural, when it is brought into perfect focus, we have something of the order of madness. So, genuine images are those which attest that tremor of the world, whatever the situation or the object: pictures of war, still-life compositions, landscape, portrait, art, and documentary. At this point, the image is something that belongs to the world; it is a part of its becoming, it participates in the metamorphosis of appearances

This idea resonates with Heidegger's notion of Gelassenheit, which to me is the core of his understanding of phenomenology as early as Sein und Zeit. Both Baudrillard and Heidegger see the possibility of a clearing only in the restoration of distance, space, and mystery in a world that has grown addicted to simulated nearness flattened cyberspace, and pornographic obscenity. This unexplored relation in the respective ideas of these two thinkers provides a springboard not just for broader scholarship but for critically understanding our current epoch.

\section{RELEASEMENT, SEDUCTION, AND THE NECESSITY OF ILLUSION}

In the obscenity of the pornographic exposure of simulation, Baudrillard calls our attention to the illusion of the object, to its secret and seduction, believing perhaps that it is only in the side of the object that humanity might find some relic of reality, if only for a while. The kind of illusion Baudrillard speaks of is not the illusion proffered by the simulation of the virtual, but the imperfect illusion of the image or the object. He $(1997,7)$ says, "Virtuality tends toward the perfect illusion. But it isn't the same creative illusion as that of the image. It is a 'recreating' illusion (as well as a recreational one), revivalistic, realistic, mimetic, hologrammatic. It abolishes the game of illusion by the perfection of the reproduction, in the virtual rendition of the real. And so we witness the extermination of the real by its double". Baudrillard $(1996,75)$ thinks that it is only in the seductive and creative illusion of the object that humanity might safeguard some semblance of salvation for the real:

It is, henceforth, the object which refracts the subject and imposes upon it its presence and its random form, its discontinuity, its fragmentation, its stereophony, and its artificial instantaneity. It is the power of the object which cuts a swathe through the very artifice we have imposed on it. There is something of revenge in this: the object becomes a strange attractor. 


\begin{abstract}
Stripped of all illusion by technology, stripped of all connotation of meaning and value, exorbitated-i. e. taken out of the orbit of the subjectit is then that it becomes a pure object, superconductive of illusion and nonmeaning. We are faced, ultimately, with two irreconcilable hypotheses: that of the extermination of all the world's illusion by technology and the virtual, or that of an ironic destiny of all science and all knowledge in which the world - and the illusion of the world - would survive.
\end{abstract}

In my opinion, Baudrillard's radical stance compliments or, at the very least, resonates with Heidegger's call for releasement. Gelassenheit as an active-willing on the part of humanity to let the thing play itself out, to take on a phenomenological stance towards the real, to "let what shows itself be seen from itself just as it shows itself as itself," is suitable comportment if we are to take Baudrillard's advice and let the object retain its secret. While Baudrillard's position still revolves around the subject-object dichotomy, which was the fundamental ground of Heidegger's critique of anthropocentric metaphysics and technology, it may very well be a creative retrieval of this modern opposition that can loosen the grip of obscenity over the current generation of humanity. While Heidegger sealed the fate of the object with Gestell as the object disappears into Bestand, Baudrillard, after having dissolved the subjectobject relation in the implosion of hyperreality, resuscitates its significance with the hypothesis that maybe, it is the illusion of the object that is the last bastion to be defended before reality is completely eradicated by the obscenity of hyperreality. And perhaps, the way to defend it (which Baudrillard does not directly comment on) is to apply Heidegger's releasement with respect to the object. It is a challenge to recognize and preserve singularities within the imploded world of simulation.

Akin to Heidegger's contemplation on the thing, which is portrayed as something which gathers the fourfold, showing precisely what is hidden as hidden in its presence (the jug, the bridge, Van Gogh's peasant shoes), Baudrillard's seduction is a call to preserve disappearance and illusion as vital forces that can keep the crime of hyperreality against reality from being perfect (by perfection, he means the total, pornographic exposure of the real and the complete destruction of any secrecy). The thing and the work of art function in the same way. Both things preserve concealment, mystery, and distance. The perfect simulation of the world, the end of illusion and the overcoming of distance is the end of the world. Perfection is death. When the world is expelled by its double, the world disappears in its absolute appearance. In this context, it can be construed that both Heidegger and Baudrillard tried to preserve the secret of the real, which they felt was in danger of being completely exposed by the age of modern technology and the epoch of obscenity, respectively. Both thinkers may be seen as wardens of the real (in the case of Heidegger, of the event of the real). Truly, even Baudrillard was more concerned with the destiny of the object than with anything else (so much so that the object figures in all of his writings from The System of Objects to his last interviews before his death in 2007). As Rex Butler $(1997,54)$ insightfully states:

The mistake Baudrillard's commentators make is that they speak of his work as simply doing away with the real: Baudrillard as the great 
contemporary thinker of the end of reality, of reality as a simulacrum, etc. In fact, as opposed to this, Baudrillard's work offers a defense of the real against the efforts of all systems (including his own) to turn it into a simulacrum, a way of thinking the real as the unsurpassable to all systems. Baudrillard is a thinker not at all of reality as a simulacrum, but of the possibility of reality when all is simulacrum.

While most of his writings since Simulacra and Simulation seem to have been obsessed with simulation and the hyperreal, Baudrillard was actually far more concerned with preserving the illusion of the world, to protect it from the invasive and reductive operations of the obscene. History, like wine, needs time to breathe in order to be real wine. When the real is instantly rendered into a news report, lights, drone perspective, expert analyses, and all, it is robbed of its ability to speak, to be properly understood by the subject. It becomes a parody of itself, absorbed in the gelatinous blob of stuff and information in cyberspace. Baudrillard $(2005,14)$ elaborates:

Think about it: it is the virtual itself that is negationist. It is the virtual that takes away the substance of the real, setting it off balance. We are living in a society of negationism by virtue of its virtuality. Disbelief reigns everywhere. No event is perceived as "real" anymore. Criminal attempts, trials, wars, corruption, opinion polls: all of that is either falsified or undecidable. State power and its institutions are the first victims of the disgrace of the principle of reality. Hence the moral urgency, in the face of rampant negationism, of recovering the "citizen's viewpoint," taking one's stand for reality, against the frailty of all information. The mirror of information has been broken. The mirror of historical time has been broken. This is why it has become possible to negate the existence of the Shoah, together with the rest (the Pentagon crash, man landing on the moon). The reign of the virtual is also the reign of the principle of uncertainty. It is the inevitable counterpart of a reality turned unreal by excess of positivity.

Meanwhile, in his essay, The Thing, Heidegger declares that "the frantic abolition of all distances brings no nearness; for nearness does not consist in shortness of distance. What is least remote from us in point of distance, by virtue of its picture on film or its sound on the radio, can remain far from us. What is incalculably far from us in point of distance can be near to us. Short distance is not in itself nearness. Nor is great distance remoteness" $(2001,163)$. Though different in actual historical contexts (Heidegger speaking from the context of the atomic age, and Baudrillard from the age of simulation), these words resonate with Baudrillard's critique of the current age of hyperreality. Distance is the keyword that can serve as a point of intersection between the two thinkers with respect to the question of the real. For Heidegger, a thing like a jug is a reminder of distance, the distance between the fourfold that gathers them together. It is their difference, their distance, that holds the jug together as an essentially meaningful thing. While representation renders the jug as a mere object that owes its existence to the making (Machenschaft) of the subject, genuine thought recognizes that 
objects are not things in this respect. It is only when the thing is allowed to shelter distance that it harbors the possibility of nearness, of humanity's nearness to the rest of the fourfold (sky, earth, divinities). The thinging of the thing, the appropriation that binds the four which bestows presencing to the thing is, in other words, a safekeeping of distance.

For Heidegger, the technological oblivion of humanity in the age of Enframing meets resistance in a thought that recognizes the difference between objects and things. The epoch of the obscene, for Baudrillard, meets resistance in the illusion of the object. While perhaps different in vocabulary, both thinkers place importance on the preservation of distance and illusion. The real must be defended, with heedful thought in Heidegger, and the preservation of seduction in Baudrillard. As Baudrillard (2005, 1) incisively remarks, "We are not talking here about philosophical morals, we are not saying 'the world is not what it should be' or 'the world is not what it used to be.' The world is the way it is. Once transcendence is gone, things are nothing but what they are, and, as they are, they are unbearable. They have lost every illusion and have become immediately and entirely real, shadowless, without commentary. At the same time, this unsurpassable reality does not exist anymore." The transcendence of the object, guaranteed by illusion, its irreducible resistance to exposure is the last mark of the real that must be preserved. Without its counterpoint, without its shadow, the real becomes absolutely identical with itself, completely dominated by the obscenity of hyperreality. Hyperreality is the death of the real by way of its perpetual resurrection within the system of instantaneous information and digital simulation. It is a living corpse, a zombie-like entity that presses forward without a sense of destiny-pure, unadulterated obscenity. To let the object remain an object, to let the thing be a thing, is to let reality disappear, and with this to allow it to appear as it is, as a singularity invested with abundant possibilities.

\section{CONCLUSION}

This work tried to show how the real has manifested itself in the epoch of modern technology, and now, in what I claim is the epoch of obscenity. Heidegger's critique of technology grounded its discourse in the modern problematic of alienation between subject and object, in what would historically result in humanity's uncanny homelessness in his own abode. The Cartesian cogito became the subiectum, which lies under everything known as real, the so-called Archimedian point of both metaphysical and epistemological claims to truth with respect to what is real. Reality, then, was equated with objectivity, that which is already represented by the subject and is therefore constituted by the gaze of consciousness. This historical possibility is opened by a destining in the history of Beyng that gave birth to Machenschaft, the power of making and manipulation that exerts its dominance over the real, which eventually translated into the challenging claim of Enframing, where all beings are seen as stockpile, as energy to be ordered for further ordering. This is where Heidegger's critique of modernity ends - in the portrayal of a world abandoned by Being, where humanity is left in a frantic goose chase for more fuel and energy to power its future plans, where everything dissolves into Bestand. 
Heidegger's insights, I felt, needed a bit of stretching, a widening of the horizon, so to speak. Given that we are living past the atomic or industrial age and are now immersed in the so-called post-industrial age of digital information, I thought perhaps that Heidegger's final depiction of the real in the epoch of modern technology may have metamorphosed into something else, that maybe the real as standing-reserve took on a new form - energy consolidated and applied in the age of digital simulation that produced the hyperreal. The hyperreal, that which is more real than the real, is not false reality or a mere construct of an intentional technological mindset but is the progeny of the implosion of the traditional dichotomies of modernity, true and false, beautiful and ugly, knowledge and opinion, etc. To see simulacra as mere technological constructs is to miss the point of Baudrillard entirely. While technology does play a big part in the production, reproduction, and proliferation of simulacra, it is, in Heidegger's words, nothing technological. Simulation, hyperreality, obscenity is an event of the unfolding of truth, a subsequent stage in the destining of Being. In the age of obscenity, the real is revealed as hyperreal. In the contemporary world of digital computing, algorithmic processing of information, virtual reality, and web-powered social media, the hyperreal is not merely rendered as a product of technology but becomes the model by which the real is understood, judged, consumed, and reproduced. Hyperreality is the fusion of the real and its opposites, which ceaselessly exposes and juxtaposes everything with everything else on the flat surface of digitality, creating a farcical world of pastiche, which is now considered as more real than the real world. Hyperreality is the world turned inside out and outside in, simultaneously.

Both Heidegger and Baudrillard placed within their own historicalphilosophical critiques key ideas that may help us understand our standing in respective epochs of Being. In the atomic age, Heidegger put forth the idea of Gelassenheit, of letting-be, and subsequently, in the epoch of the obscene, Baudrillard proffered us a rather old idea from his body of work-seduction. This work tried to establish the relationship between these two "saving powers," as Heidegger would say, with the intention of simultaneously broadening and deepening our appreciation for these two timely thinkers and providing us with a critical apparatus for navigating this brave new world of the obscene.

\section{REFERENCES}

Arva, Eugene L. 2008. Writing the vanishing real: Hyperreality and magical realism. Journal of Narrative Theory vol. 38 (1): 60-85.

Baudrillard, Jean. 1997. Art and artifact. Edited by Nicholas Zurbrugg. California: Sage Publications Ltd.

Baudrillard, Jean. 1990. Fatal strategies. Translated by P. Beitchman and W.G.J. Niesluchowski. Edited by Jim Fleming. New York: Semiotext(e).

Baudrillard, Jean. 2015 Jean Baudrillard from hyperreality to disappearance: Uncollected interviews. Edited by Richard G. Smith and David B. Clarke. Edinburgh: Edinburgh University Press.

Baudrillard, Jean. 2001. "Paroxysm." In Jean Baudrillard: Selected Writings. Edited by Mark Poster. Stanford: Stanford University Press. 276-291. 
Baudrillard, Jean. 2003. Passwords. Brooklyn: Verso Books.

Baudrillard, Jean. 1990. Revenge of the crystal. Edited and Translated by Paul Foss and Julian Pefanis. Leichardt: Pluto Press.

Baudrillard, Jean. 2001. Seduction. Translated by Brian Singer. Montreal: New World Perspectives Culture Texts Series.

Baudrillard, Jean. 1994. Simulacra and simulation. Translated by Shiela Faria Glaser. Ann Arbor: The University of Michigan Press.

Baudrillard, Jean. 1993. Symbolic exchange and death. Translated by Iain Hamilton Grant. London: Sage Publications.

Baudrillard, Jean. 2012. The ecstasy of communication. In The Ecstasy of Communication. Translated by Bernard Schütze and Caroline Schütze. South Pasadena: Semiotext(e). 19-30

Baudrillard, Jean. 2001. The Gulf War did not take place. In Jean Baudrillard: Selected Writings. Edited by Mark Poster. Stanford: Stanford University Press. 231-253.

Baudrillard, Jean. 1996. The perfect crime. Translated by Chris Turner. New York: Verso Books.

Baudrillard, Jean. 2000. The vital illusion. Edited by Julia Witwer. New York: Columbia UP.

Baudrillard, Jean. 2005. Violence of the virtual and integral reality. Translated by Marilyn Lambert-Drache. International Journal of Baudrillard Studies vol. 2 (2). https://baudrillardstudies.ubishops.ca/violence-of-the-virtual-and-integral-reality/

Baudrillard, Jean. 2009. Why hasn't everything disappeared? Translated by Chris Turner. Calcutta: Seagull Books.

Dreyfus, Hubert L. and Charles Spinosa. 2003. Heidegger and Borgmann on how to affirm technology. In Philosophy of Technology: The Technological Condition. Edited by Robert C. Scharff and Val Dusek. Oxford: Blackwell Publishing. 350361.

Heidegger, Martin. 1999. Contributions to philosophy (From Enowning). Translated by Parvis Emad and Kenneth Maly. Indiana: Indiana University Press.

Heidegger, Martin. 2006. Mindfulness. Translated by Parvis Emad and Thomas Kalary. London: Continuum International Publishing Group.

Heidegger, Martin. 1977. The age of the world picture. In The Question Concerning Technology and Other Essays. Translated by William Lovitt. New York: Harper and Row Publishers. 115-154.

Heidegger, Martin. 1977. The Question Concerning Technology. In The Question Concerning Technology and Other Essays. Translated by William Lovitt. New York: Harper and Row. 3-35.

Heidegger, Martin. 2001. The thing. In Poetry, language, Thought. Translated by Albert Hofstadter. New York: Harper Perennial. 161-184.

Joronen, Mikko. 2012. Heidegger on the history of machination. In Critical Horizons vol. 13 (3): 351-376.

McLuhan, Marshall. 2003. Understanding media: The extensions of man. CA: Gingko Press.

Schürmann, Reiner. 2003. Broken hegemonies. Translated by Reginald Lilly. Indianapolis: Indiana University Press. 
Schmidt, Dennis J. 2005. Riveted to a monstrous site. In Research in Phenomenology vol. 35. 327-339.

Zizek, Slavoj. 1999. Is it possible to traverse the fantasy in cyberspace? In The Zizek Reader. Edited by Elizabeth Wright and Edmond Wright. Oxford: Blackwell Publishers, Ltd. 102-124. 